Acta vet. scand. 1959, 1, 98-104.

From the Departments of Physiology and Radiology, Royal Veterinary College, Stockholm.

\title{
EPILEPSY IN A DOG WITH EXTENSIVE BILATERAL DAMAGE TO THE HIPPOCAMPUS
}

By

B. Andersson and S.-E. Olsson.

Green, Clemente and De Groot have recently (1957) described experimentally induced epilepsy in cats with injuries of Ammon's horns (hippocampus). In a series of experiments they studied the effect of bilateral, electrolytic, temporal lobe lesions made in the region of the amygdala. In some of the animals these lesions led to a secondary extensive bilateral injury to the hippocampus of a type which strongly suggests vascular damage and which resembles that seen in humans with sclerosis of Ammon's horns. All cats in which this kind of bilateral hippocampal damage had developed showed epileptic seizures.

A series of investigations on brains from clinical cases of epilepsy in dogs included the brain of a $3 \frac{1}{2}$ year old male poodle which showed the same kind of bilateral damage to the hippocampus as that produced experimentaly by Green et al. in the cat. A short description of the clinical and post mortem findings in this animal is given in the following.

\section{CLINICAL DATA}

The poodle was in 1953 at the age of 4 months vaccinated against distemper. He had not shown any symptoms of illness and had been in good condition until the 6th of May 1956, when he was taken home from a kennel where he had spent a fortnight. 
The dog had then no appetite and vomited in the evening. Diarrhea appeared the following day and continued until the 9th of May when the condition of the animal suddenly grew worse. He became ataxic, nervous and irritable and within a couple of hours the rectal temperature rose from slightly above normal to $42.3^{\circ} \mathrm{C}$. The dog was then anaesthetized with nembutal. When he had recovered from the anaesthesia he was still nervous but the rectal temperature had fallen to $39.4^{\circ} \mathrm{C}$. Two days later no symptoms of illness could be observed and the rectal temperature was then back to normal.

After this period of illness the dog remained in good health until towards the end of Sept. when the owner for the first time observed a short period of clonic twitching of the upper lip. From then on such twitching of the upper lip occured more and more often and on Oct. 26th it developed into a full motor fit. After a second fit the following day treatment with phenobarbital $(0.1 \mathrm{~g} /$ day $)$ was commenced. This treatment caused a temporary arrest of the seizures lasting for three weeks, but then new fits developed. Although the dose of phenobarbital was increased to $0.3 \mathrm{~g} /$ day the epileptic seizures continued to appear several times a week and the dog was therefore sacrificed on Dec. 17th 1956. Characteristics of the seizures: The first signs of an approaching fit were nervousness and clonic facial twitching, gagging and salivation. Then followed a march of movement from the face to the neck, forelimbs, trunk and hindlimbs. The movements were mainly clonic and lasted for a few minutes. No pronounced drowsiness was observed for any period of time after a fit.

\section{PATHOLOGICAL FINDINGS}

Histological examination revealed that the only part of the brain that showed apparent damage was the hippocampus which on both sides was the site of extensive gliosis, neuronophagia and loss of normal cell pattern. The atrophy of Ammon's horns had led to a marked enlargement of the lateral ventricles. Two transverse sections through the right hippocampus of the diseased dog are shown in Fig. 1 (II a. and II b.) in comparison with the corresponding sections of a normal dog ( $\mathrm{I}$ a. and I b.). Fig. 2 presents, in a smaller magnification, the complete cross section of the brain corresponding to the section II of Fig. 1. The bilateral involvement of the hippocampus is evident. 

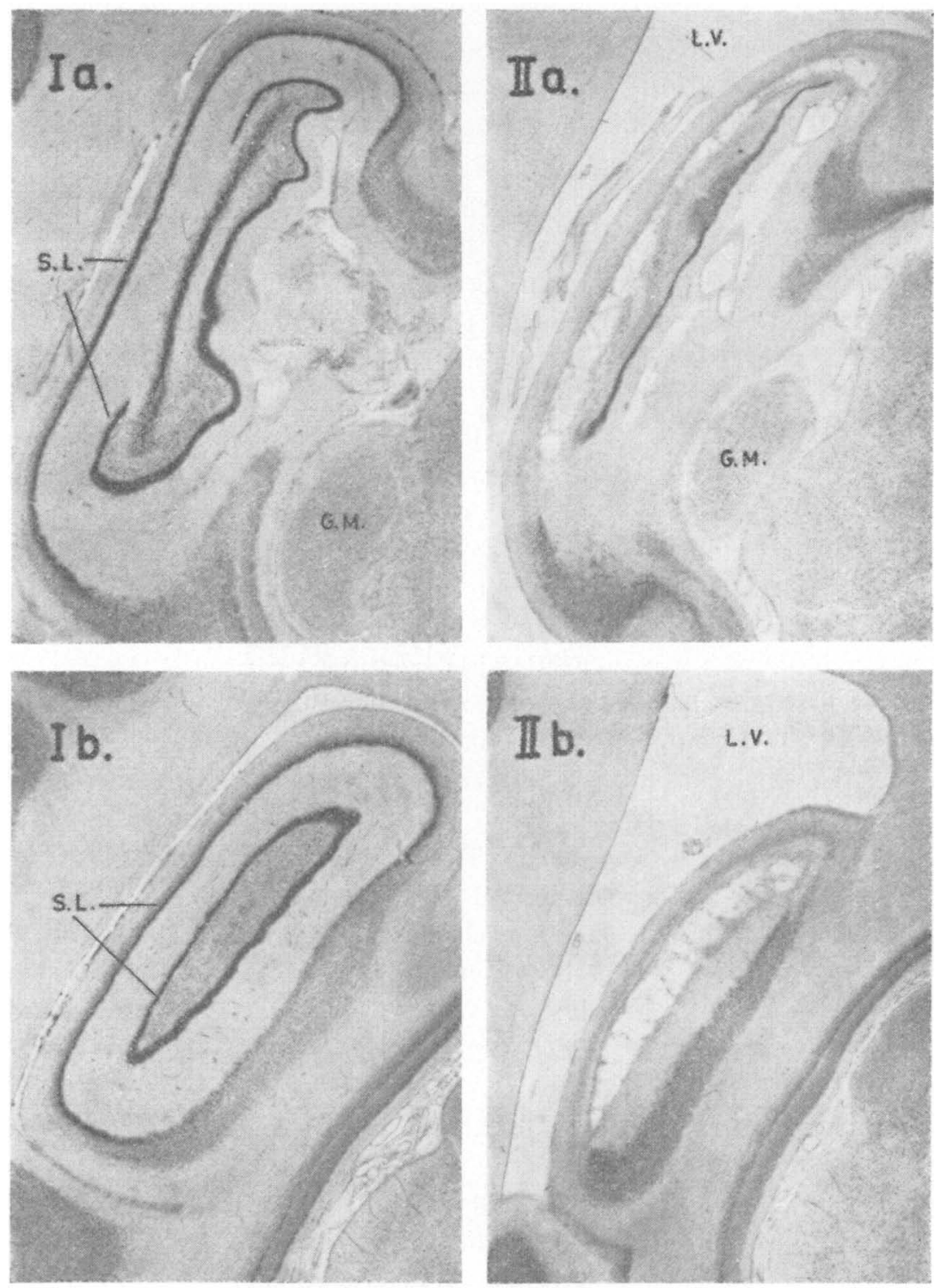

Fi g. 1.

Two transverse sections through the right hippocampus of a normal $\operatorname{dog}\left(\mathrm{I} a\right.$ and $\mathrm{I} b$ ) compared to the corresponding sections of a $3 \frac{1 / 2}{2}$ year old epileptic poodle with extensive bilateral damage to the hippocampus. (II a and II b). Note the almost complete cell loss of the layers of pyramidal cells (Stratum lucidum) and the marked atrophy of the entire hippocampus causing a widening of the lateral ventricle in the diseased animal. (magn. $6 \times$ ).

S.L. : Stratum lucidum (layer of pyramidal cells).

L.V.: Lateral ventricle.

G.M.: Corpus geniculatum mediale.

Stain: Toluidin blue (Nissl). 


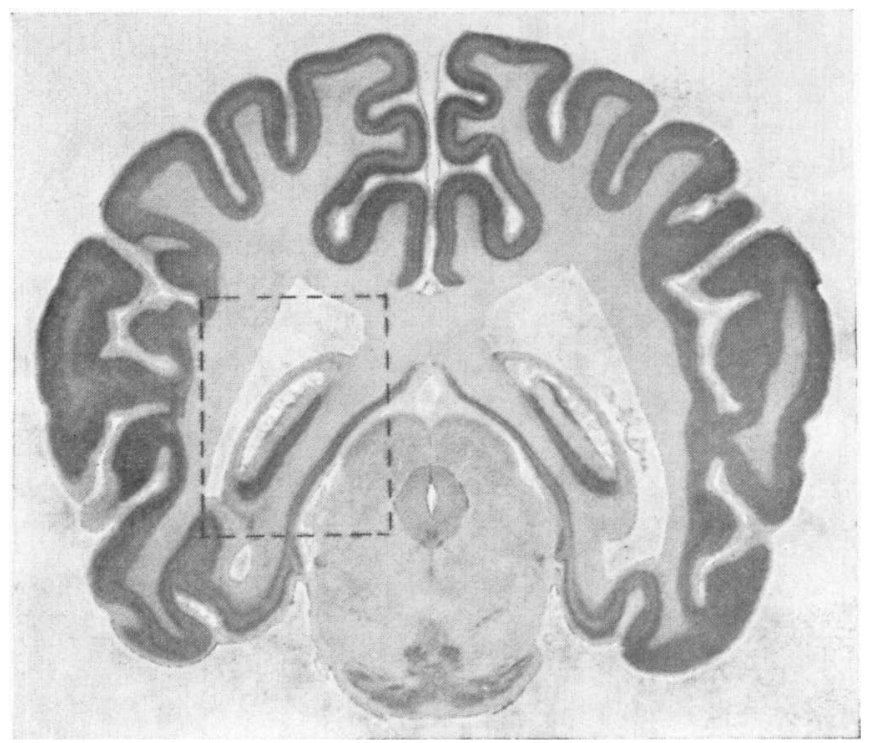

F i g. 2.

A complete cross section through the brain of the diseased dog showing the bilateral involvement of the hippocampal damage. The part of the section which is shown in higher magnification in Fig. 1 (II b) is surrounded by dotted lines. (magn. $2 \times$ ).

\section{DISCUSSION}

Light mechanical stimulation as well as electrical stimulation of the hippocampus easily causes generalized electrical discharge in the cerebral hemispheres (Green and Shimamoto, 1953). It is therefore not surprising that Kaada, Jansen and Anderson (1953), Green and Shimamoto (1953) and others have observed motor fits as a consequence of hippocampal stimulation. Furthermore, some authors have found damage to the hippocampus in an extraordinarily high percentage of cases of temporal lobe epilepsy (Stauder, 1936; Sano and Melamud, 1953). The hippocampus has a precarious blood supply and this is probably the reason why it is easily damaged by anoxemia and carbon monoxide poisoning (Meyer, 1926; Earle, Baldwin and Penfield, 1953).

By examining the brains of the cats in which small electrolytic lesions in the ventro-medial part of the temporal lobe had led to extensive bilateral injury of the Ammon's horns accompanied by epilepsy, Green et al. came to the conclusion that a tem- 
porary occlusion of the arterial blood supply of the hippocampus had occurred. In the cat the branches of the anterior choroidal and posterior cerebral arteries which supply the hippocampus with blood run in a groove along the edge of gyrus dentatus thus being quite near the site of the effective electrolytic lesions.

The close similarities between the hippocampal injuries in cats with experimental epilepsy (Green et al.) and those in the epileptic poodle might justify the suggestion that also in the latter animal there had, for some time, existed an impairment of the arterial blood supply to the hippocampus. The anamnesis suggests that this might well have happened in the beginning of May 1956, when the dog was ill and showed symptoms of a meningitis, which, judging from the pronounced hyperthermia, involved the base of the brain, and thus easily might have affected the arterial blood supply to the hippocampus.

The cause of this possible meningitis is unknown. The dog had been vaccinated against distemper and the clinical picture seems to be atypical for distemper but this disease must be taken into consideration. Unfortunately the method of examination does not allow the demonstration of any possible inclusion bodies. As mentioned before the present case is one of a number of dogs with epilepsy, the brains of which are subject to study. They have been embedded in celloidin and cut in serial sections of 50 or 100 microns. This procedure has been chosen to make possible a study of the symptomatological consequences of localized brain lesions.

\section{REFERENCES}

Earle, K. M., Baldwin, M. \& Penfield, W.: Arch. Neurol. Psychiat. 1953, $69,27$.

Green, J. D., Clemente, C. D. \& De Groot, J.: Ibidem, 1957, 78, 259.

Green, J. D. \& Shimamoto, T.: Ibidem, 1953, 70, 687.

Kaada, B. R., Jansen, J., \& Anderson, F.: Neurology, 1953, 3, 844.

Meyer, A.: Z.hr. ges. Neurol. Psychiat. 1926, 100, 201.

Sano, K. \& Melamud, N.: Arch. Neurol. Psychiat., 1953, 70, 40.

Stauder, E. M.: Arch. Psychiat. Nervenkrankh., 1936, 104, 181. 


\section{SUMMARY}

In May 1956 a 31/2 year old male poodle took ill showing symptoms of meningitis which seemingly involved the base of the brain. Five days later the animal had completely recovered from the acute illness and he remained in apparently good health until five months later when the owner for the first time observed clonic twitching of the upper lip. The lip twitching gradually developed into motor seizures involving the entire body. Treatment with phenobarbital temporarily arrested the seizures, but three weeks later motor fits reappeared and thus the dog was sacrificed in Dec. 1956. An examination of the brain revealed extensive, bilateral hippocampal damage. The possibility that a temporary impairment of the vascular supply to the hippocampus had led to the injury of Ammon's horns and that this injury later on had caused the epilepsy is discussed in the light of the experimental findings of Green et al. (1957).

\section{ZUSAMMENFASSUNG \\ Epilepsie bei einem Hund mit umfassender, bilateraler Beschädigung vom Ammonshorn.}

Ein 31/2 jähriger männlicher Pudel erkrankte am 6. Mai 1956 mit Symptomen an Meningitis welche wahrscheinlich die Gehirnhäute beim Gehirnbasis umfasste. Fünf Tage später war der Hund wieder symptomenfrei. Ende September im selben Jahr beobachtete der Besitzer zum erstenmal vorübergehende Anfälle von Zuckungen an der Oberlippe. Während der folgenden Monaten kamen diese Zuckungen immer öfters zurück und Ende Oktober entwickelten sie sich in einen epileptischen Anfall. Trotz Behandlung mit Phenobarbital wiederholten sich die Anfälle und das Tier wurde im Dezember 1956 getötet. Eine histologische Untersuchung des Gehirns zeigte eine ausgeprägte und doppelseitige Zellendegeneration im und Atrophie vom Ammonshorn. Die Möglichkeit, dass diese Beschädigung vom Ammonshorn durch eine zufällige Verschlechterung der Blutversorgung zu diesem Teil des Gehirns entstand und, dass die Epilepsie von dem beschädigten Ammonshorn ausgelöst sei, wird in der Beleuchtung der experimentellen Beobachtungen von Green und Mitarb. (1957) diskutiert.

\section{SAMMANFATTNING}

Epilepsi hos en hund med omfattende, bilateral skada i Hippocampus.

En 31/2 år gammal pudelhanne insjuknade den 6:e maj 1956 med symptom på meningit, som av allt att döma omfattade hjärnhinnorna vid hjärnbasen. Fem dagar senare var hunden symptomfri. I slutet av september samma år iakttog ägaren för första gången att hunden hade övergående anfall med ryckningar i överläppen. Under den följande månaden återkom dessa ryckningar allt oftare och $i$ slutet av oktober utvecklades de till ett fullständigt epileptiskt anfall. Sådana 
anfall återkom trots behandling med fenemal och djuret avlivades därför i december 1956.

En histologisk undersökning av hjärnan avslöjade en utpräglad och dubbelsidig celldegeneration $i$ och atrofi av ammonshornen (Hippocampus). Möjligheten att denna skada av Hippocampus orsakats av en tillfällig försämring av blodförsörjningen till denna del av hjärnan, och att epilepsin utlösts från de skadade ammonshornen diskuteras i belysning av Greens och medarbetares (1957) experimentella iakttagelser hos katt.

(Received November 7. 1957). 